\title{
Digital Mind Map Assisted Group Investigation Learning for College Students' Creativity
}

\author{
https://doi.org/10.3991/ijim.v15i05.18703 \\ Evrialiani Rosba \\ Universitas Negeri Malang, Malang, Indonesia \\ STKIP PGRI Sumatera Barat, Padang, Indonesia \\ Siti Zubaidah ${ }^{(\varpi)}$, Susriyati Mahanal, Sulisetijono \\ Universitas Negeri Malang, Malang, Indonesia \\ siti.zubaidah.fmipa@um.ac.id
}

\begin{abstract}
This study's objective was to investigate the Digital Mind Map (DMM) Assisted Group Investigation GIGI effect on students' creativity. It employed a pretest-posttest nonequivalent control group design and involved 75 students from IKIP Budi Utomo Malang, Indonesia, in the academic year of 2019/2020. Pretest and posttest were conducted to collect data on students' creativity. A rubric accompanied the tests to evaluate the keywords, material appropriateness, organization and layout, completeness of the material, creativity, image symbols, curved lines, and color used in the DMM. Assumption tests, including normality and homogeneity tests of variance, were conducted before running the ANCOVA. The analysis result showed that the DMM-GI learning model affected students' creativity $(\mathrm{p}<0.005)$. LSD test indicated a significant difference between DMM-GI and DMM-conventional learning in improving students' creativity. Therefore, it can be said that the DMM-GI learning model can be used to enhance students' creativity.
\end{abstract}

Keywords - Students' creativity; group investigation; digital mind map

\section{$1 \quad$ Introduction}

Creativity is the capability to generate new products and ideas to solve problems [1] or to enrich existing knowledge [2]. Creativity makes learning more meaningful [3] since it triggers the interaction between students' abilities and experience to produce a useful product [4]. Enhancing students' creativity is one of the essential goals of education at universities and colleges [5]. It is seen as an urgent need because creativity makes students engaged more actively in learning [6]. A creative learning environment will enable students to express their ideas freely and think creatively [7].

Research shows that Indonesian students have low creativity $[8,9,10]$ due to the learning process that cannot accommodate students' creativity. It is also demonstrated that the teachers have not optimized pedagogical strategies in the classroom [11]. Implementing a less innovative instructional strategy has resulted in students' low awareness of creativity development [12]. 
Therefore, to enhance students' creativity, changes need to be made. It is crucial to conduct active learning processes that will help students construct their knowledge [13], engage students actively in classroom discussions [14], and establish a studentstudent collaboration that indirectly affects students' creativity [15]. One of the active learning models that can be used to enhance students' creativity is Group Investigation.

Group Investigation GIGI is a learning model where students are organized and assigned into small groups to investigate [16]. Group Investigation emphasizes data collection by student individuals, data interpretation through group discussion, and students' contribution to the assigned group [17]. Group Investigation can promote student initiatives, creativity, and active learning [18]. Through group discussion in GI, students are encouraged to express unique ideas [19] and create a pleasing learning atmosphere [20].

Many researchers have reported the benefits and shortcomings of implementing GI Damini [21] and Hosseini [17] explain that GI is unlikely efficient since it is impossible to perform all GI learning steps in one meeting. For example, the evaluation stage is one of the learning steps that is mostly skipped during GI implementation. The evaluation stage aims to examine the achievement of the learning goals. If the teacher cannot carry out the assessment, students' learning outcomes cannot be identified, and thus learning cannot be adequately improved. Hargreaves [22] agrees that evaluation is important to monitor students' learning progress and provide a follow-up for improvement.

One way to conduct an evaluation is to ask students to conclude. William [23] explains that evaluation can be done through observation, interview, test, and conclusion drawing. Conclusion drawing is an activity that is conducted at the end of the lesson. At this moment, the learning topic is broken down into points [24]. Alternatively, evaluation can be performed by using technology assistance. Past studies have proved that digital tools such as smartphones and tablets help educational practitioners conduct an assessment and significantly influence the learning process [25-27]. Obviously, the application of technology in learning is essential, such as for evaluation.

Digital mind maps (DMM), which are also known as electronic mind maps [28], are compressed in a computer file [29]. Digital mind maps serve as a tool that can stimulate students' creativity and collaboration and improve students' confidence in contributing ideas in the classroom [30]. Providing a stimulus in the form of a visual element makes it easy to analyze, understand, and memorize a digital mind map. The relationship between information obtained from solving linear text problems can be seen clearly [31]. DMM will make students think quickly and remember a concept through predetermined keywords [32]. DMM offers efficient and dynamic mind maps because DMM is not limited to physical learning spaces. Through DMM, students are equipped to develop and organize ideas using higher-order thinking skills; this can ultimately increase their understanding of a concept [33].

Digital Mind Maps also can be used in Group Investigation as an evaluation tool. The instructional model resulted from this combination is called Digital Mind Map Assisted Group Investigation (DMM-GI). The DMM-GI model can improve students' creativity because it encourages students to be creative, especially in developing ideas through DMM development [34]. Students can insert various concepts and images in their DMM. The activity to connect the images to the concepts when drawing a digital 
mind map is a creative activity that requires thinking instead of remembering [35]. A digital mind map can be saved as a file that the students can share and with the teacher to collaborate [36] efficiently. Hence, the current study aimed to investigate the Digital Mind Map (DMM) Assisted Group Investigation GIGI effect on students' creativity based on the information above.

\section{$2 \quad$ Literature Review}

\subsection{Creativity}

Creativity is a thought process that helps individuals build their knowledge and solve challenging tasks in a better way [37]. Bloom places creativity in the highest dimension of cognitive processing [38]. Creativity is often defined in three ways: creativity as the final product, creativity as a creative process, and creativity as part of the social system [39]. Creativity allows humans to access the most critical skills to innovate based on prior knowledge [40]. Past studies have confirmed the important role of creativity in students' success [41] and produce new ideas [42]. Creative people create and innovate in various fields [43]. Thus, creativity determines someone's success in the future [44].

The uppermost definition of creativity is the ability to create new products and new ideas [1]. Indicators of creativity used in this study referred to the creativity indicators developed by Trefinger, Young, Selbi, dan Shepardson [45], namely fluency, flexibility, originality, and elaboration. Fluency is being fluent in generating ideas, suggestions, and thinking relevant answers within a particular time. Flexibility refers to the capability of generating various thoughts or ideas from different points of view. Originality refers to the ability to create unique ideas, suggestions, answers that no one else has thought of. Elaboration is to generate more complex ideas, suggestions, and answers.

\subsection{Group Investigation GIGI}

Group Investigation GIGI is a cooperative learning model that motivates students to communicate well and cooperate [46] as well as carry out investigations in groups to raise, analyze and solve problems [47]. GI makes students responsible for their learning activity [48]. Research shows that GI provides learning experiences through creativity in group presentations using visual media that are more interesting and less tedious [49]. Therefore, this type of learning is more effective than conventional learning.

Group Investigation can facilitate students' ability to exchange materials, knowledge, ideas, and backgrounds and share what is relevant for investigating [16]. Learning in GI consists of six stages, namely; 1) choosing a topic, 2) planning a task, 3 ) conducting an investigation, 4) preparing a report investigation, 5) present the investigation report, and 6) evaluating [50]. GI has three main advantages, namely, inquiry, knowledge, and group dynamics [51]. 


\subsection{Digital Mind Map (DMM)}

Digital Mind Map (DMM) is a Mind Map (MM) designed with a computer program or smartphone application or via a website [52]. Some experts explain that DMM is an electronic mind map with the same results and concept of the creation process [29], [53]. DMM essentially refers to the theory proposed by Buzan [54], mentioning that DMM consists of five components, including the center, branches, keyword, image, and color. DMM can be arranged with colors, numbers, fonts, images, or videos in a non-linear format using a computer application [36]. Available applications such as Coggle, Freemind, Mindjet, MindNode, XMind, SpiderScribe.net, iMindMap, MindMeister, and Popplet are useful to assist in creating, organizing, and storing DMM [55]. Also, DMM accommodates the arrangement and visualization of thought processes.

DMM can act as a tool to stimulate activity, creativity, and collaboration between students and increase their confidence in contributing ideas in the classroom [56]. The utilization of digital technology in the learning process can improve student skills and knowledge. Similarly, Al-Haj Bedar \& Al-Shboul [57] state that digital technology in the classroom helps students focus on the learning process. Al-Jarf's [58] reports that computerized mind maps can encourage creativity because they allow students to be more adept at generating and forming ideas that are complex to write about. Apart from that, DMM can also be used as an evaluation tool [59]. DMM can be used to assess students' creative thinking [60]. The relationship between indicators of creativity and mind map's essential parts can be seen in Table 1 .

Table 1. The Relationship between Indicators of Creativity and Mind Map Components

\begin{tabular}{|l|l|}
\hline \multicolumn{1}{|c|}{ Indicators of creativity } & \multicolumn{1}{c|}{ Mind Map Components } \\
\hline Fluency & Branch \\
\hline Flexibility & Branch, keyword \\
\hline Originality & Mind map center, branch, picture, color \\
\hline Elaboration & Mind map center, branch, picture, color \\
\hline
\end{tabular}

Source: Susiana [61].

The mind maps generated by the participants were evaluated using a rubric of mind map creativity developed and modified from Monet \& Connor [62]. The relationship between indicators of the rubric and mind map components can be seen in Table 2 .

Table 2. The Relationship between Indicators of Creativity Rubric and Mind Map Components

\begin{tabular}{|l|l|}
\hline \multicolumn{1}{|c|}{ Indicators of the Rubric } & \multicolumn{1}{c|}{ Mind Map Components } \\
\hline Keywords & Keywords \\
\hline Material Appropriateness & Branch, keyword \\
\hline Organization and Layout & Mind map center, branch, picture, keyword \\
\hline Material Completeness & Mind map center, keyword, branch, picture \\
\hline Creativity & Mind map center, keyword, branch, picture, color \\
\hline Symbols, Images, and Curved Lines & Picture, branch \\
\hline Color & Mind map center, branches, and links \\
\hline
\end{tabular}




\subsection{Digital Mind Map Assisted Group Investigation (DMM-GI)}

Digital Mind Map Assisted Group Investigation is a GI-based learning model in which implementation is assisted by digital technology in DMM. This constructivist learning model aims to improve students' ability to develop knowledge and independence to generate creativity and find steps to solve a problem, both individually and in groups. Constructivist learning directs students to organize themselves and take an active role in education by setting goals, monitoring, and evaluating their progress [63]. The constructivist-based DMM-GI model can help students develop knowledge, solve problems individually and in groups, assess learning progress, and train students' independent learning, leading to creativity.

The DMM-GI model consists of six stages, namely: 1) choosing a topic, 2) planning a task, 3) carrying out an investigation, 4) preparing a report investigation, 5) present the investigation report, and 6) evaluating using DMM. The DMM-GI model is expected to enhance students' creativity in developing ideas and making learning more fun and interesting.

\section{Methods}

\subsection{Design of the study}

The present study used a pretest-posttest nonequivalent control group design. The pretest and posttest were administered to two treatment groups (experimental and control). The experimental group was treated using the DMM-GI model, and the control group performed learning using DMM-assisted conventional learning. The research design is presented in Table 3.

Table 3. The Research Design

\begin{tabular}{|l|c|c|c|}
\hline \multicolumn{1}{|c|}{ Group } & Pretest & Treatment & Post-test \\
\hline DMM-GI & $\mathrm{O}_{1}$ & $\mathrm{X}_{1}$ & $\mathrm{O}_{2}$ \\
\hline DMM-Conventional & $\mathrm{O}_{3}$ & $\mathrm{X}_{2}$ & $\mathrm{O}_{4}$ \\
\hline
\end{tabular}

Note: $\mathrm{O} 1=$ pretest score of the experimental group

$\mathrm{O} 2=$ posttest score of the experimental group

X1 = Digital Mind Maps Assisted Group Investigation Learning

X2 $=$ Digital Mind Maps Assisted Conventional Learning

$\mathrm{O} 3=$ pretest score of the control group

$\mathrm{O} 4=$ posttest score of the control group

\subsection{Participants of the study}

This study was conducted in the odd semester of 2019/2020. The study participants consisted of 75 Biology students enrolled in the Vascular Plant Botany course in IKIP Budi Utomo Malang, Indonesia. The participants' Grade Point Average (GPA) was analyzed using a t-test to determine the sample's homogeneity in academic ability. The t-test result showed no significant difference between the two classes, where class A (34 students) obtained an average score of 3.39, and class B (41 students) obtained 
an average score of 3.46. The experimental and control groups were selected randomly from the two classes. Digital Mind Maps assisted Group Investigation (DMM-GI) was implemented in the experimental group, while Digital Mind Maps assisted conventional (DMM-Conventional) was applied in the control group.

\subsection{Research procedures}

The initial stage of this study was the pretest administration. On the test, the students were asked to create digital mind maps based on the following topics: Pteridophyta, Gymnospermae, and Angiospermae. The purpose of conducting the pretest was to determine the students' initial creativity before being involved in the experiment. The DMM-GI model was applied in the experimental group, and the DMMConventional model was implemented in the control group for 12 meetings. The learning steps carried out in the two classes are shown in Table 4. The final stage of the study was to conduct the posttest. On the posttest, the participants were asked to create digital mind maps based on the topics that had been learned. The students had to save the maps in pdf format and send them to the teacher via e-mail for evaluation.

Table 4. Stages of Learning in DMM and DMM-Conventional Classes

\begin{tabular}{|c|c|c|c|}
\hline \multicolumn{2}{|r|}{ DMM-GI } & \multicolumn{2}{|c|}{ DMM-Conventional } \\
\hline $\begin{array}{l}\text { Stages of Learn- } \\
\text { ing }\end{array}$ & Learning Activities & Stages of Learning & Learning Activities \\
\hline $\begin{array}{l}\text { Organizing } \\
\text { students into } \\
\text { groups } \\
\end{array}$ & $\begin{array}{l}\text { The students are divided heterogeneously } \\
\text { into 5-6 based on their academic ability. }\end{array}$ & $\begin{array}{l}\text { Encouraging } \\
\text { students to learn }\end{array}$ & $\begin{array}{l}\text { Encouraging students } \\
\text { to learn the materials } \\
\text { being discussed. }\end{array}$ \\
\hline $\begin{array}{l}\text { Selecting topics } \\
\text { and planning } \\
\text { tasks }\end{array}$ & $\begin{array}{l}\text { Each group selects a topic, then students in } \\
\text { the group form a plan for investigation ac- } \\
\text { cording to their roles. }\end{array}$ & $\begin{array}{l}\text { Delivering the } \\
\text { materials }\end{array}$ & $\begin{array}{l}\text { The lecturer delivers } \\
\text { the materials. }\end{array}$ \\
\hline $\begin{array}{l}\text { Conducting an } \\
\text { investigation }\end{array}$ & $\begin{array}{l}\text { Every group member investigates by seeking } \\
\text { information, analyzing data, drawing conclu- } \\
\text { sions, exchanging ideas, discussing, and } \\
\text { clarifying. }\end{array}$ & $\begin{array}{l}\text { Assigning students } \\
\text { into groups }\end{array}$ & $\begin{array}{l}\text { The students are } \\
\text { divided into a group of } \\
5-6 .\end{array}$ \\
\hline $\begin{array}{l}\text { Preparing a } \\
\text { report }\end{array}$ & $\begin{array}{l}\text { Group members select essential concepts that } \\
\text { need to be reported, compile a report, prepare } \\
\text { a presentation, share the presentation assign- } \\
\text { ments. }\end{array}$ & Group discussion & $\begin{array}{l}\text { The students discuss in } \\
\text { groups and do the task } \\
\text { assigned by the lectur- } \\
\text { er. }\end{array}$ \\
\hline $\begin{array}{l}\text { Presenting the } \\
\text { report }\end{array}$ & $\begin{array}{l}\text { Group members present in turn according to } \\
\text { the tasks assigned to them and answer ques- } \\
\text { tions from other groups. }\end{array}$ & $\begin{array}{l}\text { Presenting the } \\
\text { discussion result }\end{array}$ & $\begin{array}{l}\text { One particular group is } \\
\text { asked to present the } \\
\text { discussion result; those } \\
\text { who are not given a } \\
\text { chance to present have } \\
\text { to provide feedback to } \\
\text { the presenters in } \\
\text { comments, sugges- } \\
\text { tions, or questions. } \\
\end{array}$ \\
\hline
\end{tabular}




\begin{tabular}{|l|l|l|l|}
\hline Evaluating & $\begin{array}{l}\text { Each group evaluates the materials studied, } \\
\text { creates digital mind maps based on the evalu- } \\
\text { ation results, saves them in pdf format, and } \\
\text { then sends them to the lecturer via e-mail. }\end{array}$ & $\begin{array}{l}\text { Conducting an lecturer asks the } \\
\text { evaluation } \\
\text { students to conclude } \\
\text { the discussion, transfer } \\
\text { it into DMM, save the } \\
\text { DMM in pdf format, } \\
\text { and then send them to } \\
\text { the lecturer via e-mail. }\end{array}$ \\
\hline
\end{tabular}

\subsection{The instrument of the study}

The rubric used to assess the students' creativity was adopted from Monet \& Connor [62]. The rubric was used to assess the keywords, material appropriateness, organization and layout, completeness of the material, creativity, image symbols, curved lines, and color used in the students' DMM (Table 5). The rubric used a score range of 0-4 for each of the indicators evaluated, where $4=$ very good, $3=$ good, $2=$ fair, 1 $=$ bad, $0=$ very bad. Before use, the rubric underwent expert validation, where experts were invited to evaluate the rubric. The evaluation criteria for rubric validity ranged from $0 \leq \mathrm{X} \leq 0.50$ for highly invalid, $0.50 \leq \mathrm{X} \leq 1.50=$ invalid; $1.50<\mathrm{X} \leq 2.50=$ fairly valid; $2.50<\mathrm{X} \leq 3.50=$ valid; and $3.50<\mathrm{X} \leq 4.00=$ highly valid. Based on the expert validation, the rubric obtained an average score of 3.81 , which suggested that the rubric in use was highly valid and can be used in data collection.

Table 5. Creativity Rubric to Evaluate Digital Mind Map

\begin{tabular}{|c|c|c|c|}
\hline No & Indicator & Descriptor & Score \\
\hline \multirow{5}{*}{1} & \multirow[t]{5}{*}{ Keywords } & The keywords are written in words & 4 \\
\hline & & The keywords are written in a sentence & 3 \\
\hline & & The keywords are written in several sentences & 2 \\
\hline & & The keywords are written in a paragraph & 1 \\
\hline & & No keywords used & 0 \\
\hline \multirow{5}{*}{2} & \multirow{5}{*}{$\begin{array}{l}\text { Material's } \\
\text { comprehen- } \\
\text { siveness }\end{array}$} & The mind map contains the correct sections and understanding. & 4 \\
\hline & & The mind map contains a few inaccuracies, but most of the links are correct. & 3 \\
\hline & & The mind map contains some inaccuracies that are not fundamental. & 2 \\
\hline & & The mind map contains many inaccuracies of the topic. & 1 \\
\hline & & The mind map contains the wrong topic's interpretations. & 0 \\
\hline \multirow{5}{*}{3} & \multirow[t]{5}{*}{$\begin{array}{l}\text { Organization } \\
\text { and Layout }\end{array}$} & $\begin{array}{l}\text { The mind map is organized with a complete branch structure with interrelated } \\
\text { topics. }\end{array}$ & 4 \\
\hline & & $\begin{array}{l}\text { The mind map is organized with a complete branch structure but less related } \\
\text { topics. }\end{array}$ & 3 \\
\hline & & $\begin{array}{l}\text { The mind map is organized with an incomplete branch structure with less related } \\
\text { topics. }\end{array}$ & 2 \\
\hline & & $\begin{array}{l}\text { The mind map is organized with an incomplete branch structure with unrelated } \\
\text { topics. }\end{array}$ & 1 \\
\hline & & The mind map has no branch structure organization. & 0 \\
\hline & \multirow{4}{*}{$\begin{array}{l}\text { Material's } \\
\text { completeness } \\
\text { (topics and } \\
\text { sub-topics) }\end{array}$} & The mind map is complete because all topics and sub-topics are represented. & 4 \\
\hline 4 & & $\begin{array}{l}\text { The mind map is complete, but one or two essential topic sections and sub- } \\
\text { sections are missing. }\end{array}$ & 3 \\
\hline 4 & & The mind map is not complete enough to represent each topic and sub-topic. & 2 \\
\hline & & $\begin{array}{l}\text { The mind map is incomplete because some of the topic sections and sub-topics } \\
\text { are missing. }\end{array}$ & 1 \\
\hline
\end{tabular}




\begin{tabular}{|c|c|c|c|}
\hline No & Indicator & Descriptor & Score \\
\hline & & The mind map contains no material completeness (topics and sub-topics). & 0 \\
\hline \multirow{5}{*}{5} & \multirow[t]{5}{*}{ Creativity } & $\begin{array}{l}\text { Different ideas are developed from one idea into more than } 15 \text { branches, with } \\
\text { logical layouts and a good presentation. }\end{array}$ & 4 \\
\hline & & $\begin{array}{l}\text { Different ideas are developed from one idea into more than 10-15 branches, with } \\
\text { logical layouts and a good presentation. }\end{array}$ & 3 \\
\hline & & $\begin{array}{l}\text { Different ideas are developed from one idea into five branches, with logical } \\
\text { layouts but a confusing presentation. }\end{array}$ & 2 \\
\hline & & $\begin{array}{l}\text { Different ideas are developed from one idea into less than five branches, with } \\
\text { confusing layouts and presentations. }\end{array}$ & 1 \\
\hline & & There is no development of the idea. & 0 \\
\hline \multirow{5}{*}{6} & \multirow{5}{*}{$\begin{array}{l}\text { Symboliza- } \\
\text { tion: pictures } \\
\text { and curves }\end{array}$} & $\begin{array}{l}\text { The mind map contains images/symbols in the central idea, the main branch, and } \\
\text { other branches connected by curved lines. }\end{array}$ & 4 \\
\hline & & $\begin{array}{l}\text { The mind map contains images/symbols only on the main branch, other branches } \\
\text { connected by curved lines. }\end{array}$ & 3 \\
\hline & & $\begin{array}{l}\text { The mind map contains images/symbols only on other branches connected by } \\
\text { curved lines. }\end{array}$ & 2 \\
\hline & & The mind map does not contain any images/symbols but uses curved lines. & 1 \\
\hline & & The mind map does not contain any images/symbols nor curved lines. & 0 \\
\hline \multirow{5}{*}{7} & \multirow[t]{5}{*}{ Color use } & Various colors are used in the mind map (the center, branches, and links). & 4 \\
\hline & & Various colors are used in the mind map (branches and links). & 3 \\
\hline & & Only one color is used in the mind map (the center, branches, and links). & 2 \\
\hline & & Only one color is used in the center of the mind map. & 1 \\
\hline & & No color is used in the mind map. & 0 \\
\hline
\end{tabular}

Source: Modified from Monet \& Connor [62].

\subsection{Data analysis}

Data analysis was performed in three stages:

1. The students' creativity score was calculated using the following formula:DMM creativity $=\frac{\text { score obtained }}{\text { maximum score }}$ X 100 (1)

2. SPSS 23 was used to analyze the results of the pretest and the posttest. The normality and homogeneity of variance were examined using Kolmogorov-Smirnov and Levene tests, respectively. The test results showed that the data had a normal distribution with a score of 0.131 for pre-creativity and 0.120 for post-creativity and distributed homogeneously with p-value 0.447 ( $p>0.05$ ).

3 . After the data were proven normal and homogeneous, ANCOVA was run to investigate the instructional models' effect on student's creativity. An LSD test followed this process.

\section{$4 \quad$ Results and Discussion}

The ANCOVA analysis results on the students' DMM creativity can be seen in Table 6 . 
Table 6. The Results of the ANCOVA Analysis

\begin{tabular}{|l|c|c|c|c|c|}
\hline \multicolumn{1}{|c|}{ Source } & $\begin{array}{c}\text { Type III } \\
\text { Sum of Squares }\end{array}$ & df & Mean Square & F & Sig. \\
\hline Corrected Model & $1346.682^{\mathrm{a}}$ & 2 & 673.341 & 22.979 & .000 \\
\hline Intercept & 1872.650 & 1 & 1872.650 & 63.908 & .000 \\
\hline Pre-Creativity & 446.730 & 1 & 446.730 & 15.245 & .000 \\
\hline Model & 272.436 & 1 & 272.436 & 9.297 & .003 \\
\hline Error & 2109.780 & 72 & 29.303 & & \\
\hline Total & 451989.796 & 75 & & & \\
\hline Corrected Total & 3456.463 & 74 & & & \\
\hline \multicolumn{7}{|l}{ a. R Squared $=.390$ (Adjusted R Squared $=.373$ ) }
\end{tabular}

Table 6 shows an F-calculated of 9.297 with a significance level of 0.003 (<alpha 0.05). Therefore, it was concluded that the DMM-GI and DMM-conventional models affected student's creativity. The covariance analysis was followed by an LSD test with a significance level of 0.05 to investigate the mean scores between the two treatment groups. The results of the LSD test can be seen in Table 5.

Table 7. The Results of the LSD test on Student's creativity

\begin{tabular}{|c|l|c|c|c|c|c|}
\hline No. & \multicolumn{1}{|c|}{ Model } & Pretest & Post-Test & Difference & Average & LSD Notation \\
\hline 1. & DMM-Conventional & 51.58 & 73.53 & 21.95 & 74.96 & $\mathrm{a}$ \\
\hline 2. & DMM-GI & 57.23 & 80.49 & 23.26 & 79.30 & $\mathrm{~b}$ \\
\hline
\end{tabular}

Based on Table 7, it can be concluded that there was a difference in the mean scores between the DMM-GI and DMM-conventional groups. The mean score achieved by the DMM-GI group (79.30) was higher than that obtained by the DMMconventional group (74.96). The highest pretest and posttest scores were found in the DMM-GI group (Figure 1).

The statistical analysis results showed that the DMM-GI model affected students' creativity on Vascular Plant Botany. The students' creativity was developed through the learning activities conducted in DMM-GI, which included carrying out an investigation, writing a report, and conducting an evaluation.

At the investigation stage, the students were trained to independently collect information from relevant learning resources such as textbooks or journal articles. The information collected by each group member was formulated into an idea. The idea was then discussed, clarified, and analyzed with other group members to generate more creative ideas. The investigation stage encouraged the students to explore many ideas, enrich knowledge, and share a lot of information with their peers [64]. The investigation stage also allowed students to solve problems and inquiries based on what had been learned in the classroom [65]. These activities can stimulate students' thinking skills, knowledge construction, and creativity [66]. 


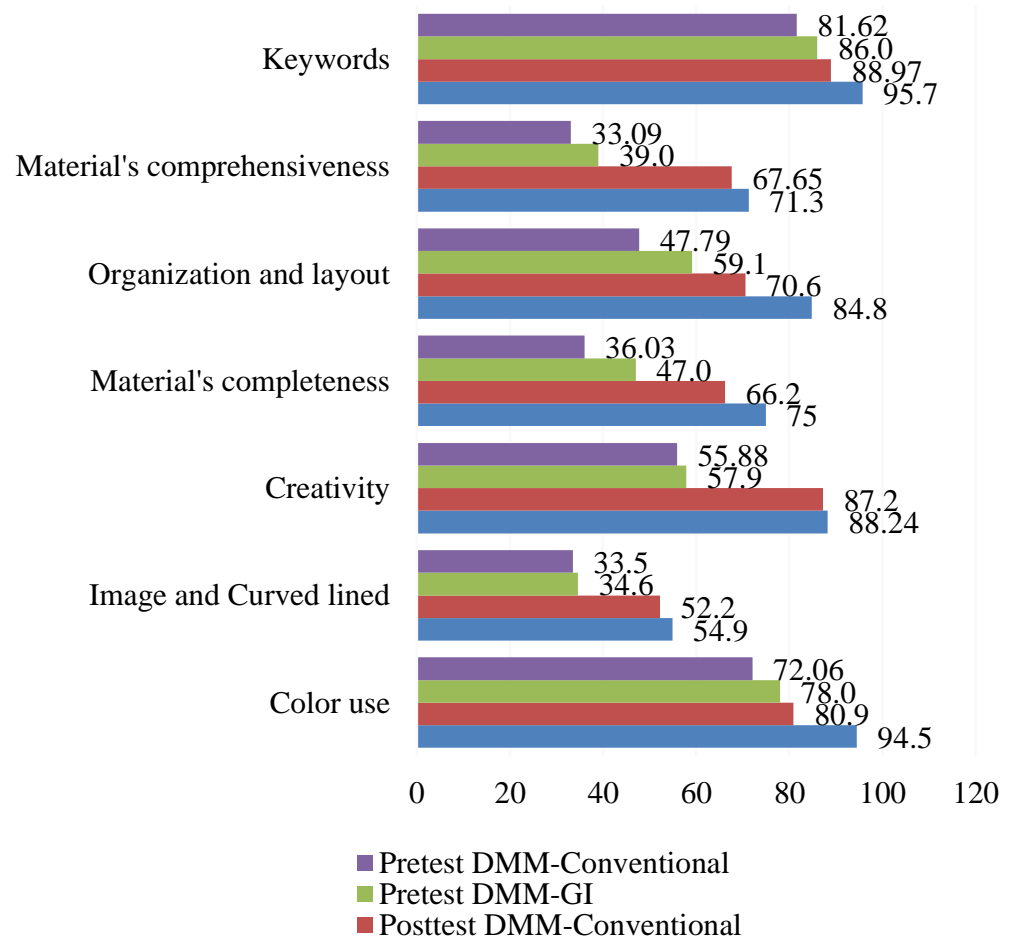

Fig. 1. Students' Creativity Scores through DMM

Each group had to write an attractive report containing sufficient and comprehensive materials and generate ideas and explore their creativity in the next stage. Creativity is associated with recognizing ideas, finding new solutions, and maximizing efforts to produce something different [67]. The students were instructed to generate the correct concept based on each group member's investigation and thoughts and then put them into a report. Writing reports can be an alternative task to increase students' creativity [68].

The final stage, which was conducting an evaluation, focused on the students' knowledge during the learning process and the Digital Mind Maps (DMM) final product. Digital Mind Maps as an assessment tool guided and supported the students to achieve the learning goals [69], better understand and memorize the whole concept [28]. Besides, it encouraged the students to improve their concept knowledge [70]. In making mind maps, the students were required to compile, organize, and reconstruct relevant knowledge and understand the contents of knowledge independently [71]. Figure 2 and Figure 3 contain the examples of the participants' DMM creativity, both in GI-DMM and Conventional-DMM groups. 


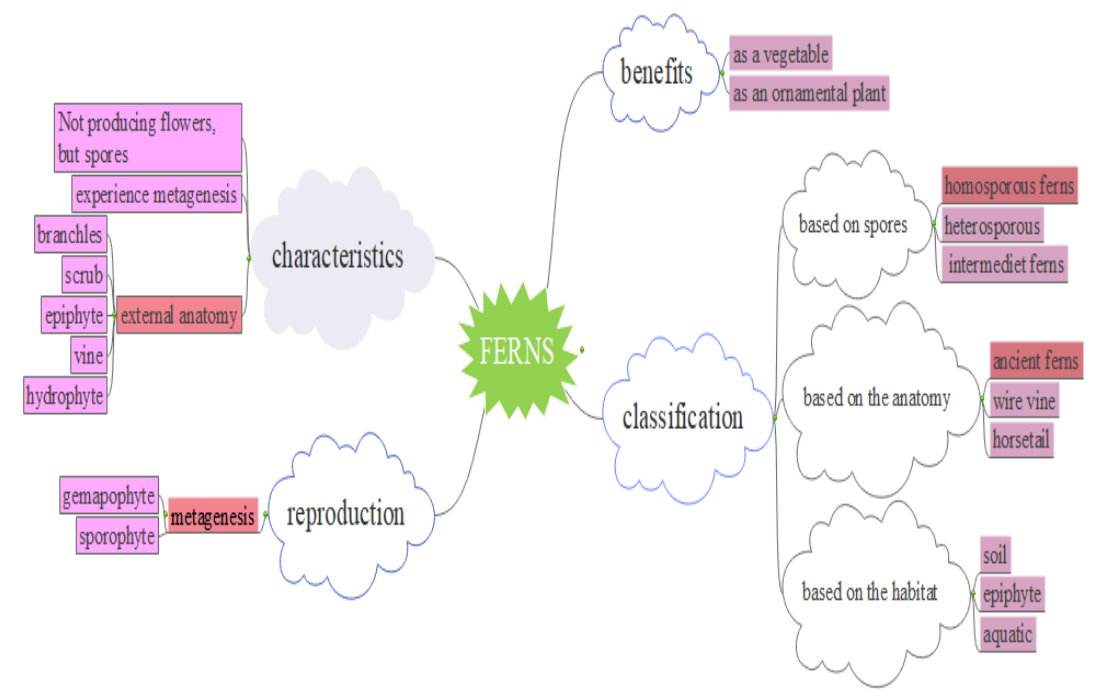

a) Pretest

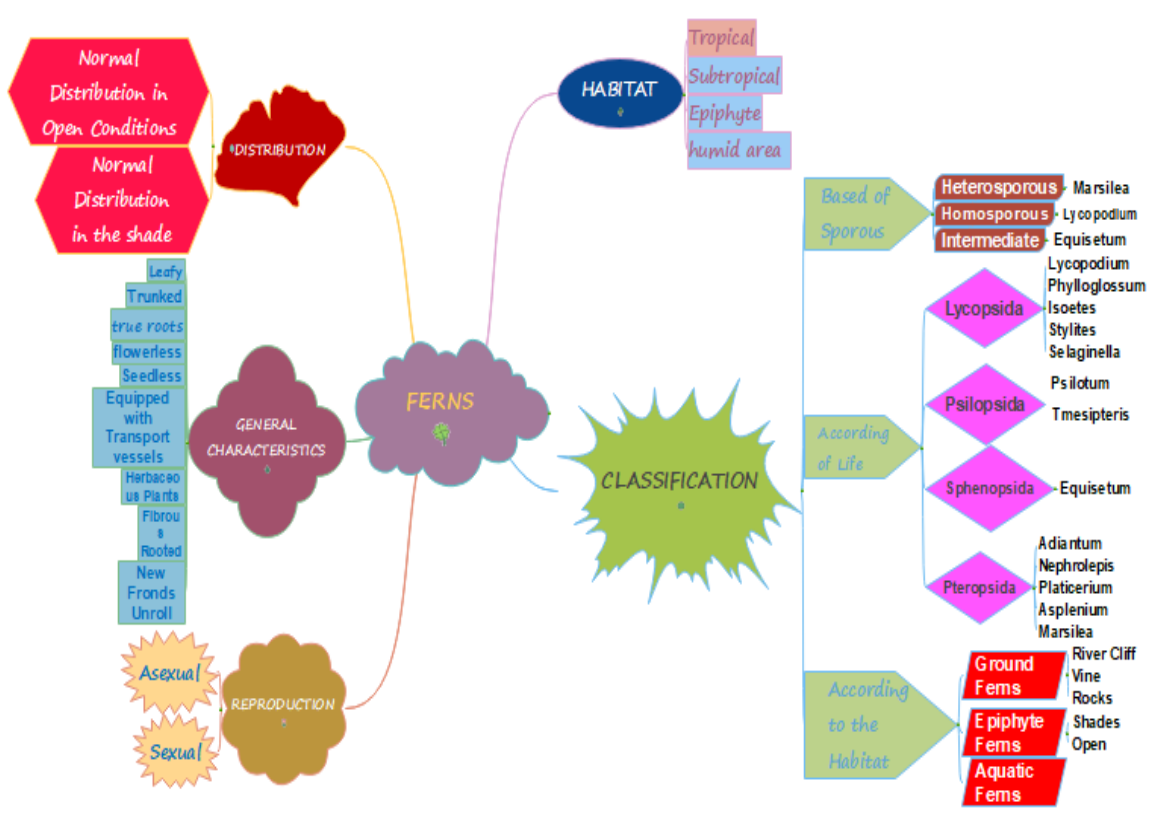

b) Posttest

Fig. 2. The DMM-GI students' Digital Mind Maps 
Figure 2 contains two digital mind maps about fern that the DMM-GI students worked on in the pretest and posttest. In the pretest, the word "fern" was written in the center of the mind map as a keyword, connected by a curved line to the four main branches explaining the characteristics, reproduction, classification, and fern benefits. Each branch was assigned the same color. Meanwhile, the Digital Mind Map produced in the posttest increased the number of main branches from four to five. The creativity shown on these digital mind maps can be explained through the branches generated on the maps. For example, the digital mind map done in the posttest had several main branches describing the characteristics and classification of fern that were further divided into sub-levels of branches. Also, each branch was colored differently so that the mind map is easier to remember and is more appealing to students. Color makes DMM more effective and provides tremendous benefits for memory [72].

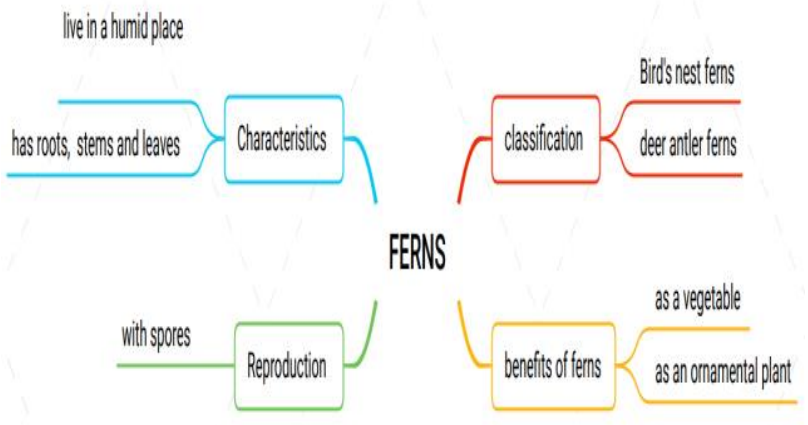

a) Pretest

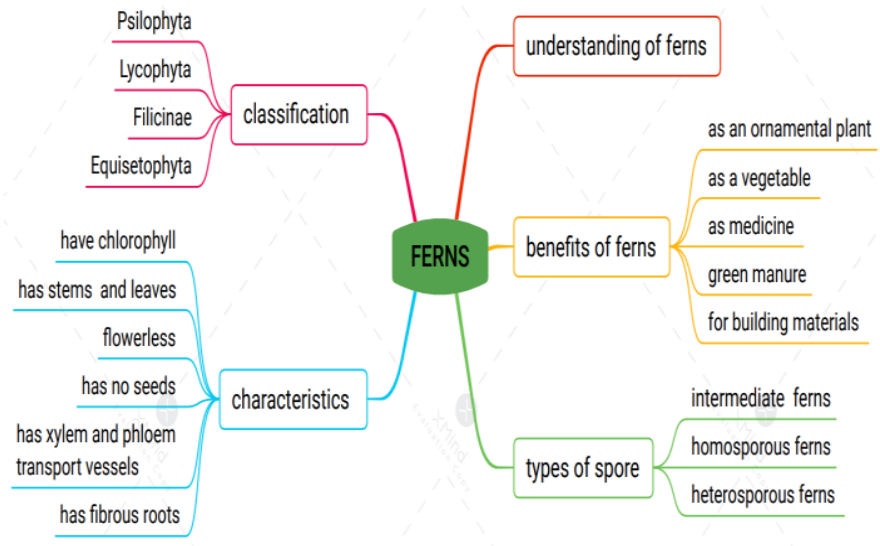

b) Post-test

Fig. 3. The DMM-Conventional students' Digital Mind Maps 
Figure 3 presents two digital mind maps about "fern" created by the DMMConventional students in the pretest and posttest. A difference was found between the mind maps produced by the DMM-GI students and DMM-Conventional students in the way they described their ideas into the map's branches. For example, the word "fern" was written in the mind map center as the keyword. Curved lines were put to connect this keyword to the four main branches containing the characteristics, reproduction, classification, and fern benefits. The main branch and the tiers of the main branch are of the same color. In the posttest, the word "fern" was written in the center of the map; then, curved lines were drawn to connect the keyword to the five main branches and sub-levels of the same branches color. Several branches were developed from one branch level to represent the ideas that emerged. This suggests that DMMConventional students have not developed ideas due to insufficient knowledge of the topic. Creative tasks can help individuals improve their learning performance because there is a relationship between task structure and initial knowledge [73].

The differences between the DMM-GI and DMM-Conventional students' creativity (Figure 2 and Figure 3 ) are described in Table 8 through each creativity indicator.

Table 8. The differences between the DMM-GI and DMM-Conventional Students' Creativity

\begin{tabular}{|c|c|c|c|c|c|}
\hline \multirow[b]{2}{*}{ No } & \multirow[b]{2}{*}{ Indicator } & \multicolumn{2}{|l|}{ Pretest } & \multicolumn{2}{|c|}{ Post-test } \\
\hline & & DMM-Conventional & $D M M-G I$ & $\begin{array}{c}\text { DMM- } \\
\text { Conventional }\end{array}$ & $D M M-G I$ \\
\hline 1. & Keywords & $\begin{array}{l}\text { The ideas are unclear or lack } \\
\text { connection to the keywords. }\end{array}$ & $\begin{array}{l}\text { Some of the ideas } \\
\text { are unclear or lack } \\
\text { connection to the } \\
\text { keywords. }\end{array}$ & $\begin{array}{l}\text { Some of the ideas } \\
\text { are unclear or lack } \\
\text { connection to the } \\
\text { keywords. }\end{array}$ & $\begin{array}{l}\text { The ideas are } \\
\text { clear and con- } \\
\text { nected to the } \\
\text { keywords. }\end{array}$ \\
\hline 2. & $\begin{array}{l}\text { Material } \\
\text { Appropriate- } \\
\text { ness }\end{array}$ & $\begin{array}{l}\text { Main ideas are associated } \\
\text { with a lot of material appro- } \\
\text { priateness. }\end{array}$ & \begin{tabular}{|l|} 
Main ideas are \\
associated with \\
some material \\
appropriateness, \\
but the topic is still \\
understandable.
\end{tabular} & $\begin{array}{l}\text { Main ideas are } \\
\text { associated with a } \\
\text { little material } \\
\text { appropriateness, } \\
\text { but most of the } \\
\text { links are correct, } \\
\text { relevant to the } \\
\text { topic. }\end{array}$ & $\begin{array}{l}\text { Main ideas are } \\
\text { associated with } \\
\text { the right parts } \\
\text { and correct } \\
\text { understanding } \\
\text { without misun- } \\
\text { derstanding the } \\
\text { topic. }\end{array}$ \\
\hline 3. & $\begin{array}{l}\text { Organization } \\
\text { and Layout }\end{array}$ & $\begin{array}{l}\text { One part contains at least one } \\
\text { branch }\end{array}$ & $\begin{array}{l}\text { One part contains } \\
\text { a limited number } \\
\text { of branches. }\end{array}$ & $\begin{array}{l}\text { One part already } \\
\text { contains some } \\
\text { parts, although } \\
\text { there are missing } \\
\text { links between } \\
\text { branches. }\end{array}$ & $\begin{array}{l}\text { The map con- } \\
\text { tains a complete } \\
\text { structure of } \\
\text { branches. }\end{array}$ \\
\hline 4. & $\begin{array}{l}\text { Material } \\
\text { Complete- } \\
\text { ness }\end{array}$ & $\begin{array}{l}\text { The material is incomplete } \\
\text { because some important } \\
\text { topics and subtopics are } \\
\text { missing from the DMM. }\end{array}$ & $\begin{array}{l}\text { The material is } \\
\text { incomplete be- } \\
\text { cause the topics } \\
\text { and subtopics are } \\
\text { not represented } \\
\text { entirely by the } \\
\text { DMM. }\end{array}$ & $\begin{array}{l}\text { The material is } \\
\text { complete, but some } \\
\text { parts are less } \\
\text { connected to the } \\
\text { topics and subtop- } \\
\text { ics. }\end{array}$ & $\begin{array}{l}\text { The material } \\
\text { completely } \\
\text { defines the main } \\
\text { idea, topic, } \\
\text { subtopics, and } \\
\text { all-important } \\
\text { information. }\end{array}$ \\
\hline
\end{tabular}




\begin{tabular}{|l|l|l|l|l|l|}
\hline 5. & Creativity & $\begin{array}{l}\text { The DMM lacks creativity by } \\
\text { containing less than five } \\
\text { branches. }\end{array}$ & $\begin{array}{l}\text { The DMM lacks } \\
\text { creativity by } \\
\text { containing less } \\
\text { than five branches. }\end{array}$ & $\begin{array}{l}\text { The DMM shows } \\
\text { creativity by con- } \\
\text { taining 10-15 } \\
\text { branches }\end{array}$ & $\begin{array}{l}\text { The DMM } \\
\text { shows creativity } \\
\text { by containing } \\
\text { more than 15 } \\
\text { branches. }\end{array}$ \\
\hline 6. & $\begin{array}{l}\text { Image Sym- } \\
\text { bols and } \\
\text { Curved Lines }\end{array}$ & $\begin{array}{l}\text { The DMM does not contain } \\
\text { image symbols but uses } \\
\text { curved lines. }\end{array}$ & $\begin{array}{l}\text { The DMM does } \\
\text { not contain image } \\
\text { symbols but uses } \\
\text { curved lines. }\end{array}$ & $\begin{array}{l}\text { The DMM does not } \\
\text { contain image } \\
\text { symbols on the } \\
\text { main idea or } \\
\text { branches, but uses } \\
\text { contains image } \\
\text { cumbols on the } \\
\text { symain idea or } \\
\text { main branches } \\
\text { connect branches. } \\
\text { that are con- } \\
\text { nected with } \\
\text { curved lines. }\end{array}$ \\
\hline 7. & Color Use & $\begin{array}{l}\text { There are a few similar colors } \\
\text { applied. The colors do not } \\
\text { show any connection between } \\
\text { topics. }\end{array}$ & $\begin{array}{l}\text { There are a few } \\
\text { similar colors } \\
\text { applied. The colors } \\
\text { do not show any } \\
\text { connection be- } \\
\text { tween topics. }\end{array}$ & $\begin{array}{l}\text { The different colors } \\
\text { applied show some } \\
\text { connections be- } \\
\text { tween topics. }\end{array}$ & $\begin{array}{l}\text { The different } \\
\text { colors applied } \\
\text { show connec- } \\
\text { tions between } \\
\text { topics. }\end{array}$ \\
\hline
\end{tabular}

Based on Table 8, it was known that there were differences in the students' DMM creativity, indicated by the difference in the pretest and posttest scores for each indicator measured. The experimental (DMM-GI) students performed better than the control (DMM-Conventional) students in creativity. This may be caused by the fact that ideas elaborated through the keywords into branches are connected with different colors, hence producing creativity. A digital mind map comprises meaningful keywords and symbols relating to the topics discussed, curved lines, and various color distribution [74]. The process of making a mind map using software or an application becomes an interactive game for students because this fun-filled activity allows students to exchange ideas and feel the satisfaction of creating a beautiful and informative product [75].

Every student can use a unique way to build a digital mind map based on their ideas. The findings show that each student had a different way of exploring colors, lines, branches, and images to convey ideas [76]. The use of DMM allows students to move freely in an unlimited learning space by easily drawing branches, deleting ideas, or replacing them with new ones [77]. Digital Mind Maps allow the creators to draw, fix, save, and convert maps into PDF files or images [78], so DMM can facilitate learning.

The study results showed that the DMM-GI instructional model had a positive effect on students' creativity. One of the advantages of the GI-DMM model is that it enables students to work collaboratively in small groups to carry out investigations, make reports and presentations, and evaluate students' ability to develop ideas, apply existing knowledge and add new knowledge. In line with Sojayapan \& Khaisang's [48] research, Group Investigation can bring out creativity through investigation and presentation. Also, learning using DMM will help students generate many ideas and develop creativity. 


\section{Conclusion}

The current study showed that the Digital Mind Map Assisted Group Investigation (DMM-GI) effectively improved student's creativity. It was proven that the mean score obtained by the DMM-GI group was higher than that achieved by the DMMconventional group. Therefore, the implementation of DMM-GI in the classroom is highly recommended.

Furthermore, this study suggests that DMM-GI could compensate for the Group Investigation weaknesses and play a vital role as an evaluation tool in the process. This study's findings suggest that Digital Mind Map (DMM) can be used as a tool to evaluate student's creativity products. This study only involved Biology students as the participants; therefore, other researchers should study the potential of DMM-GI in improving the students' creativity from other departments or different levels of education. Future studies can also examine the effect of DMM-GI on other capability or skills.

\section{Acknowledgement}

We want to acknowledge the kind assistance from the Head of IKIP Budi Utomo Malang and their students. They were patiently involved in the research activities and were willing to work collaboratively until the end.

\section{$7 \quad$ References}

[1] Glaveanu, P.V. (2018). Educating which creativity. Thinking Skills and Creativity, 27: 2532 https://doi.org/10.1016/j.tsc.2017.11.006

[2] Dell, B., Garrick, R., Romanowski, C. \& Slifka, M. (2012). Using Mind Mapping to Influence Creativity and Innovation. Institute of Technology. Retrieved from http://www.indiana.

[3] Thomsen, Bo. S. (2020). Assessing Creativity: A palette of possibilities. The LEGO Foundation. An Essay Collection.

[4] Leggett, N. (2017). Early Childhood Creativity: Challenging Educators in Their Role to Intentionally Develop Creative Thinking in Children. Early Childhood Education Journal, vol. 45, no. 6, pp. 845-853. https://doi.org/10.1007/s10643-016-0836-4

[5] Długosz, M.W. (2015). Stimulating the Development of Creativity and Passion in Children and Teenagers in Family and School Environment - Inhibitors and Opportunities to Overcome them. Procedia - Social and Behavioral Sciences 174 (2905 - 2911). https://doi.org/10.1016/j.sbspro.2015.01.1027

[6] Yusnaeni, Corebima, A. D., Susilo, H. \& Zubaidah, S. (2017). Creative Thinking of Low Academic Student Undergoing Search Solve Create and Share Learning Integrated with Metacognitive Strategy. International Journal of Instruction, vol. 10, no. 2, pp. 245-262. https://doi.org/10.12973/iji.2017.10216a.

[7] Al Hashimi, S., Al Muwali, A., Zaki, Y. \& Mahdi, N. (2019). The Effectiveness of Social Media and Multimedia-Based Pedagogy in Enhancing Creativity among Art, Design, and 
Digital Media Students. iJET - Vol. 14, No. 21. https://doi.org/10.3991/ijet.v14i21. $\underline{10596}$

[8] Zuhriyah, M., Agustina, R.K. \& Fajarina, M. (2018). The Influence of Students' Creativity to Construct Sentences toward Their Speaking Skill. Register Journal. Vol. 11, No. 1, pp 118. DOI: https://doi.org/10.18326/rgt.v11i1.1-18

[9] Dwikoranto, Munasir, Setiani, R., Suyitno, Surasmi, W.A., Tresnaningsih. \& Pramonoadi. (2019). Effectiveness of Project Based Laboratory Learning to Increase Student's Science Process Skills and Creativity. IOP Conf. Series: Journal of Physics: Conf. Series 1491. Doi: https://doi.org/10.1088/1742-6596/1491/1/012006

[10] Widiati, I., Turmudi. \& Juandi. (2019). Pre-service Mathematics Teachers Creativity in Designing Mathematics Assessment Based on Education For Sustainable Development. International Conference on Mathematics and Science Education 2019 (ICMScE 2019). Journal of Physics: Conference Series 1521. doi: https://doi.org/10.1088/17426596/1521/3/032061.

[11] Birsa, E. (2018). Teaching Strategies and the Holistic Acquisition of Knowledge of the Visual Arts. Center for Educational Policy Studies Journal, 8(3), 187-206. https://doi.org/10.26529/cepsj.39

[12] Khairullina, N., Bakhtizin, R., Gaisina, L., Konsintseva, T. \& Belonozhko, L. (2016). Development of Creative Activity of Students in the System of the Organizational Culture of the Modern University. International Journal of Environmental \& Science Education. Vol 11. No.4, pp. 2171-2184.

[13] Reigeluth, C.M. \& Carr-Chellman, A.A. (2009). Understanding Instructional Theory. In. C.M. Reigeluth \& A.A. Carr-Chellman (Eds.), Instructional Design Theories and Models Volume III: Building a Common Knowledge Base (P: 3-26). New York: Routledge. https://doi.org/10.4324/9780203872130

[14] Singh, S. \& Yaduvanshi, S. (2015). Constructivism in Science Classroom: Why and How. International Journal of Scientific and Research Publications, Vol 5, Issue 3.

[15] Romero, M., Hyvönen, P. \& Barberà, E. (2012). Creativity in Collaborative Learning across the Life Span. Creative Education. Vol.3, No.4, pp. 422-429. DOI: https://doi.org/10.4236/ce.2012.34066

[16] Tan, I. G.C., Sharan, S. \& Lee, C.K. (2006). Group Investigation and Student learning an Experiment in Singapore Schools. Singapore: Marshall Cavendish Academic.

[17] Hosseini, S. M. A. (2014). Competitive Team-Based Learning versus Group Investigation with Reference to the Language Proficiency of Iranian EFL Intermediate Students. International Journal of Instruction Vol.7, No.1. www.e-iji.net

[18] Arinda, Y., Wilujeng, I. \& Kuswanto, H. (2019). The Application Group Investigation GIGI Learning Model-Assisted Phet to Facilitate Student Scientific Work Skills. International Journal of Educational Research Review, vol. 4, no. 2, pp. 254-261. https://doi.org/10.24331/ijere.518069

[19] Breslin, D. (2017). Group Creativity and the Time of the Day. Studies in Higher Education https://doi.org/10.1080/03075079.2017.1413082

[20] Mun, F. T., Ngoh, K. G. \& Lian, S. C. (2004). Using Group Investigation for Chemistry in Teacher Education. Asia-Pacific Forum on Science Learning and Teaching Journal, vol. 5, no. 1. https://doi.org/10.1007/s10734-010-9387-6.

[21] Damini, M. (2014). How the Group Investigation Model and the Six-Mirror Model Changed Teachers' Roles and Teachers' and Students' Attitudes Towards Diversity. Intercultural Education, Vol. 25, No. 3, pp. 197-205. https://doi.org/10.1080/14675986.2014. $\underline{917794}$ 
[22] Hargreaves, E. (2005). Assessment for learning? Thinking Outside the (Black) Box. Cambridge Journal of Education Vol. 35, No. 2, pp. 213-224 https://doi.org/10.1080/ $\underline{03057640500146880}$

[23] Wiliam, D. (2010). An Integrative Summary of the Research Literature and Implications for a new Theory of Formative Assessment. In H. L. Andrade \& G. J. Cizek (Eds.), Handbook of formative assessment (pp. 18-40). New York, NY: Taylor \& Francis

[24] Gultom, E. (2016). Assessment and Evaluation in EFL Teaching and Learning. Proceeding of ISELT FBS University of Padang.Vol 4, No.1

[25] Vidakis, N.; Barianos, A.; Trampas, A.; Papadakis, Stamatios; Kalogiannakis, M. and Vassilakis, K. (2019). Generating Education in-Game Data: The Case of an Ancient Theatre Serious Game. In Proceedings of the 11th International Conference on Computer Supported Education - Volume 1: CSEDU, ISBN 978-989-758-367-4, pages 36-43. DOI: https://doi.org/10.5220/0007810800360043

[26] Dorouka, P., Papadakis, S., \& Kalogiannakis, M. (2020). Tablets and apps for promoting robotics, mathematics, STEM education and literacy in early childhood education. International Journal of Mobile Learning and Organisation, 14(2), 255-274. https://doi.org/10. 1504/ijmlo.2020.10026334

[27] Vidakis N., Barianos A.K., Trampas A.M., Papadakis S., Kalogiannakis M., Vassilakis K. (2020) in-Game Raw Data Collection and Visualization in the Context of the "ThimelEdu" Educational Game. In: Lane H.C., Zvacek S., Uhomoibhi J. (eds) Computer Supported Education. CSEDU 2019. Communications in Computer and Information Science, vol 1220. Springer, Cham. https://doi.org/10.1007/978-3-030-58459-7_30

[28] Tungrapa, T. (2015). Effect of Using the Electronic Mind Map in the Educational Research Methodology Course for Master-Degree Students in the Faculty of Education. International Journal of Information and Education Technology, Vol. 5, No. 11. https://doi.org/10. 7763/ijiet.2015.v5.615

[29] Guerrero, J.M. (2018). Data Visualization of Complex Information through Mind Mapping in Spain and the European Union. Federal Data Science, 103-138. https://doi.org/10. 1016/b978-0-12-812443-7.00008-9

[30] Nong, B.K., Pham, T.A. Tran, T.N.M. (2010). Integrate the Digital Mindmapping into Teaching and Learning Psychology. Teacher Training Component - ICT, VVOB Education Program Vietnam

[31] Naghmeh-Abbaspour, B., Rastgoo, V., Fathi, N. \& Yek, M.Z. (2019). The Use of Mindomo Software to Improve the Logical Development of EFL Learners' Writing. International Journal of Innovation, Creativity and Change. Vol 8, no. 12. www.ijicc.net

[32] Buzan, T. (2010). Mind maps for business: Revolutionize your business thinking and practice. Great Britain: BBC Active.; vol. 22, no. 6, pp. 36-41

[33] Novak, J. D., and Cañas, A. J. (2006). The Theory Underlying Concept Maps and How to Construct Them (Technical Report IHMC CmapTools 2006-01). Pensacola, Florida: Florida Institute for Human and Machine Cognition

[34] Qi, A. (2018). A Study of the Effect of Implementing Intellectual Property Education with Digital Teaching on Learning Motivation and Achievements. Eurasia Journal of Mathematics, Science \& Technology Education, vol. 14, no. 6, pp. 2445-2452. https://doi.org/10. 29333/ejmste/89498.

[35] Papushina, I., Maksimenkova, O., \& Kolomiets, A. (2017). Digital Educational Mind Maps: A Computer Supported Collaborative Learning Practice on Marketing Master Program. Interactive Collaborative Learning, 17-30. https://doi.org/10.1007/978-3-319$\underline{50337-0 \_2}$ 
[36] Pati, P. (2003). Managing Creativity and Innovation. asci.org.in Daley, B. J., Morgan, S., \& Beman, S. B. (2016). Concept Maps in Nursing Education: A Historical Literature Review and Research Directions. Journal of Nursing Education, vol. 55, no. 11, pp. 631-639. https://doi.org/10.3928/01484834-20161011-05

[37] Anderson, L.W. \& Krathwohl, D.R. (2001). A Taxonomy for learning, Teaching and Assessing: A Revision of Bloom's Taxonomy Educational Objectives. New York. Longman.

[38] Gibson, C., Hancock, H \& Irlbeck, E. (2017). Cultivating Creativity: Faculty Conceptions of Creativity in Agricultural Communication Students. Journal of Applied Communications. Vol. 102, no. 1. https://doi.org/10.4148/1051-0834.1753

[39] Brodin, E. M. (2018). The Stifling Silence around Scholarly Creativity in Doctoral Education: Experiences of Students and Supervisors in Four Disciplines. Higher Education, 75(4), 655-673 https://doi.org/10.1007/s10734-017-0168-3

[40] Runco, M. A. \& Jaeger, G. J. (2012). The Standard Definition of Creativity. Creativity Research Journal, 24, 92-96. https://doi.org/10.1080/10400419.2012.650092

[41] Castillo-vergara, M., Galleguillos, N. B., Cuello, L. J., Alvarez-marin, A. \& Acuña-opazo, C. (2018). Does Socioeconomic Status Influencee Student Creativity? Thinking Skills and Creativity, 142-152 https://doi.org/10.1016/j.tsc.2018.07.005

[42] Beghetto, R.A. \& Kaufman, J.C. (2014). Classroom Contexts for Creativity, High Ability Studies, vol. 25, no. 1, pp. 53-69. https://doi.org/10.1080/13598139.2014.905247

[43] Mumford, M.D. (2003). Where Have We Been, Where Are We Going? Taking Stock in Creativity Research. Creativity Research Journal, vol. 15, no. 2-3, pp. 107-120. https://doi.org/10.1080/10400419.2003.9651403

[44] Kuo, H.-C., Burnard, P., McLellan, R., Cheng, Y., \& Wu, J. (2017). The Development of Indicators for Creativity Education and a Questionnaire to Evaluate its Delivery and Practice. Thinking Skills and Creativity, 24, 186-198. https://doi.org/10.1016/j.tsc.2017. $\underline{02.005}$

[45] Treffinger, D. J., Young, G. C., Selby, E. C., \& Shepardson Cindy. (2002). Assessing Creativity: A Guide for Educators. Florida: The National Research Center on the Gifted and Talented

[46] Johnson, D. W., Johnson, R. T., \& Smith, K. (2007). The State of Cooperative Learning in Postsecondary and Professional Settings. Educational Psychology Review, vol. 19, no. 1, pp. 15-29 https://doi.org/10.1007/s10648-006-9038-8

[47] Asyari, M., Al Muhdar, M.H.I., Susilo, H \& Ibrohim. (2017). Improving Critical Thinking Skills through the Integration of Problem Based Learning and Group Investigation. International Journal for Lesson and Learning Studies, vol. 5, no. 1, pp. 36-44. https://doi.org/10.1108/ijlls-10-2014-0042

[48] Sojayapan, C. \& Khaisang, J. (2018). The effect of a Flipped Classroom with Online Group Investigation on Student's Team Learning Ability. Kasetsart Journal of Social Science xxx 1-6 https://doi.org/10.1016/j.kjss.2018.02.003

[49] Jacob, G.M. \& Lawson, N.D. (2017). Collaboration Can Promote Students' Creativity. James Cook University Singapore.

[50] Sharan, S., Y. Sharan. \& Tan, I. G. (2013). "The Group Investigation Approach to Cooperative Learning." In The International Handbook of Collaborative Learning, edited by C. E. Hmelo-Silver, A. M. O’Donnell, C. Chan, and C. Chinn, 351-369. New York: Taylor and Francis. https://doi.org/10.4324/9780203837290.ch20

[51] Akçay, N. O. \& Doymus, K. (2012). The Effect of GI and Cooperative Learning Techniques Applied in Teaching Force and Motion Subjects on Students' Academic Achievements. Journal of Turkish Science Education, vol. 11, no. 4. 
[52] Al-Badwoi, A.S. (2015). Using E-Mind Mapping in Learning at IBR I College of Applied Sciences. Global Journal of Computer Science and Technology: H Information \& Technology vol. 15 , no. 4, Version 1.0

[53] Karim, A.R. (2018). Technology-Assisted Mind Mapping Technique in Writing Classrooms: An Innovative Approach. International Journal of Academic Research in Business and Social Sciences Vol. 8, No. 4. https://doi.org/10.6007/ijarbss/v8-i4/4146

[54] Buzan. (2004). The Mind Map Book. London. BBC.

[55] Vittu, P \& Gilles, R. (2016). Mind Mapping: Making Connections with Images and Color. Delta Journal of Education. Vol. 6, no. 2.

[56] Umami, R. (2016). The Effectiveness of Using Digital Mind Mapping toward the Students' Achievement in Writing Descriptive Text to be the First Grader at MAN 2 Tulungagung in Academic Year 2015/2016. Thesis. English Education Departement Faculty of Tarbiyah and Teacher Training. IAIN Tulungagung.

[57] Al-Haj Bedar, R \& Al-Shboul, M. (2020). The Effect of Using STEAM Approach on Developing Computational Thinking Skills among High School Students in Jordan. IJIM Vol. 14, No. 14. https://doi.org/10.3991/ijim.v14i14.14719

[58] Al-Jarf, R. (2009). Enhancing Freshman Students' Writing Skills with a Mind Mapping Software. Paper presented at the 5th International Scientific Conference, eLearning and Software for Education, Bucharest.

[59] Elsaeed, E. A. (2012). Educational e-Mind Maps. Arab eLearning Academy.

[60] Rahayu, P. Susantini, E. \& Oka, D.N. (2018). Development of Creative Mind Map Rubric to Assess Creative Thinking Skills in Biology for the Concept of Environmental Change. International Journal of Innovation and Research in Educational Sciences. Vol. 5, no. 2.

[61] Susiana, N. (2013). Development of Mind Map Rubric to Measure Creativity Of Students In Basic Chemistry Course For The Concept Of "Material And Its Changes. Fifth International Conference on Science and Mathematics Education CoSMEd 2013 Penang, Malaysia 11 - 14 November 2013

[62] Monet, B \& O'Connor, R. (2011). The Use of Mind Mapping as an Assessment Tool, Dublin: Institute of Technology Tallaght.

[63] Bruning, R.H., Schraw, G.J., Norby, M.M. \& Ronning, R.R. (2004). Cognitive Psychology and Instructional, 4th Edition. University of Nebraska, Lincoln.

[64] Zingaro, D. (2008). Group Investigation: Theory and Practice. Ontario Institute for Studies in Education, Toronto, Ontario

[65] Adnan, A. H. M. \& Zamari, Z. M. (2012). “I am a Techno-Rebel!” Malaysian Academics $\&$ their Personal Experiences of Progressing Into E-Learning. Procedia - Social and Behavioral Sciences, 67: 61-72 https://doi.org/10.1016/j.sbspro.2012.11.307

[66] Fourniyati, I.R., Nuswowati, M. \& Cahyono, E. (2020). The Effects of Projects Based Chemistry Learning Model, Assisted by Chemsong Video to Students' Learning Completeness and Creativity. Journal of Innovative Science Education vol. 9, no. 3, pp. 314 320 https://doi.org/10.15294/jise.v9i1.36750

[67] Batey, M. (2012). The Measurement of Creativity: From Definitional Consensus to the Introduction of a New Heuristic Framework. Creativity Research Journal, vol. 24, no. 1, pp. 55-65. https://doi.org/10.1080/10400419.2012.649181

[68] Tan, L. S., Lee, S. S., Ponnusamy, L. D., Koh, E. R. \& Tan, K. C. K. (2016). Fostering Creativity in the Classroom for High Ability Students: Context Does Matter. Education Sciences, vol. 6, no. 4, 36. https://doi.org/10.3390/educsci6040036

[69] Jbeili, I.M.A. (2013). The Impact of Digital Mind Maps on Science Achievement among Sixth Grade Students in Saudi Arabia. 13th International Educational Technology Confer- 
ence. Procedia - Social and Behavioral Sciences 103: 1078 - 1087 https://doi.org/10. 1016/j.sbspro.2013.10.435

[70] Lai, C.H. Jong, B.S. \& Hsia, Y.T. (2020). Applying Concept Map to Game-Based Concept Assessment. iJIM - Vol. 14, No. 6. http://www.i-jim.org https://doi.org/10. 3991/ijim.v14i06.12057

[71] Ren, Y \& Jiang, X. (2019). A Mind Map Teaching Mode for Sports Anatomy based on 3DBody. iJET - Vol. 14, No. 10. https://doi.org/10.3991/ijet.v14i10.10776

[72] Arulselvi, E. (2017). Mind Maps in Classroom Teaching and Learning. The Excellence in Education Journal. Vol. 6, no. 2

[73] Wu, C. H., Cheng, Y., Ip, H. M. \& McBride-Chang, C. (2005). Age Differences in Creativity: Task Structure and Knowledge Base. Creativity Research Journal, vol. 17, no. 4, pp. 321-326. https://doi.org/10.1207/s15326934crj1704_3

[74] Astriani, D., Susilo, H., Suwono, H. \& Lukiati, B. (2020). Mind Mapping in Learning Models: A Tool to Improve Student Metacognitive Skills. iJET - Vol. 15, No. 6. https://doi.org/10.3991/ijet.v15i06.12657

[75] Sabbah, S. (2015). The Effect of College Students' Self-Generated Computerized Mind Mapping on their Reading Achievement. International Journal of Education and Development using ICT, vol. 11, no. 3.

[76] Chan, Z. C. Y. (2013). Exploring Creativity and Critical Thinking in Traditional and Innovative Problem-based Learning Groups. Journal of Clinical Nursing, 22(15016), 22982307. https://doi.org/10.1111/jocn.12186

[77] Gomez Betancur, M. I. \& King, G. (2014). Using Mind Mapping as a Method to help ESL/EFL Students to Connect Vocabulary and Concepts in Different Contexts. Trilogia: Revisa Ciencia Technologia Sociedad, 10: 69-85.

[78] Kim, S.Y. \& Kim, M.R. (2012). Kolb's Learning Styles and Educational Outcome: Using Digital Mind Map as a Study Tool in Elementary English Class. International Journal for Educational Media and Technology, Vol.6, No.1, pp.4-13.

\section{Authors}

Evrialiani Rosba is a lecturer at STKIP PGRI West Sumatera, located in Jalan Gunung Pangilun, Padang 25137, Indonesia. She is also a post-graduate student at Universitas Negeri Malang, Indonesia. (E-mail: evrialianirosba@ stkip-pgri-sumbar.ac.id).

Siti Zubaidah. Professor, Researcher, Universitas Negeri Malang, Jalan Semarang 5, Malang 65145, Indonesia. (E-mail: siti.zubaidah.fmipa@um.ac.id)

Susriyati Mahanal. Professor, Researcher, Universitas Negeri Malang, Jalan Semarang 5, Malang 65145, Indonesia. (E-mail: susriyati.mahanal.fmipa@um.ac.id)

Sulisetijono. Doctor, Researcher, Universitas Negeri Malang, Jalan Semarang 5, Malang 65145, Indonesia. (E-mail: sulisetijono.fmipa@um.ac.id))

Article submitted 2020-09-21. Resubmitted 2020-12-30. Final acceptance 2020-12-31. Final version published as submitted by the authors. 